\title{
COOKING PERFORMANCE OF A DEVELOPED BIOGAS BURNER (STOVE)
}

\author{
Awulu J.O, Iyidiobu B.N., Ugbede J \\ Department of Agricultural and Environmental Engineering \\ Federal University of Agriculture Makurdi, Benue State
}

\begin{abstract}
A biogas burner (stove) was developed and its performance evaluated. The main features of the stove are: the frame, the burner head, injector, mixing tube, burner pots and primary air control valve. The stove functions by connecting to a biogas plant $\left(3 \mathrm{~m}^{3}\right.$ continuousflow Indian type biogas plant). The stove was evaluated by time measurements for boiling 1 litre of water and cooking $70 \mathrm{~g}$ each, of rice, yam and beans at initial conditions of 1 atm and $28{ }^{\circ} \mathrm{C}$. The time taken for boiling and cooking each of the food items was noted and recorded using a stop watch. The pressure drop for the stove was determined with the aid of a twin $u$ - tube manometer. Biogas consumption rates were determined using known standards and formulae. The gas consumption rate for the developed stove was $5.687 \mathrm{~m}^{3} / \mathrm{h}$. Mean time measurements obtained were $5 \mathrm{~min}, 34.33 \mathrm{~min}, 34.66 \mathrm{~min}$, and $49.33 \mathrm{~min}$ for boiling water, cooking rice, yam and beans respectively. These amounted to Biogas consumption values of $0.474 \mathrm{~m}^{3}, 3.254 \mathrm{~m}^{3}, 3.285 \mathrm{~m}^{3}$, and $4.778 \mathrm{~m}^{3}$ for water, rice, yam and beans in the same order. The boiling rate of water was 0.2 lit /min while mean cooking rates were $2.044 \mathrm{~g} / \mathrm{min}, 2.020 \mathrm{~g} / \mathrm{min}$ and $1.419 \mathrm{~g} / \mathrm{min}$ for rice, yam and beans respectively. The efficiency values obtained are $42 \%$ for boiling water, $63 \%$ for cooking rice, $61 \%$ for cooking yam, and $30 \%$ for cooking beans. These efficiency values are high in comparison to previous works and indicate an improvement in the use of biogas for cooking.
\end{abstract}

Keywords- biogas, cooking, stove, biogas-plant, consumption-rates, efficiency

\section{INTRODUCTION}

Biogas is a gas rich in either methane or a combination of carbon dioxide, Hydrogen and Nitrogen, produced under low oxygen conditions [1]. Pure methane is odourless and colourless and burns with clear blue flame. Its calorific value is 20 Mega Joules (MJ) per m3 and burns with 60 percent efficiency in a conventional biogas stove [2]. One type of biogas can be produced by anaerobic digestion or fermentation of biodegradable material such as biomass, manure or sewage, municipal waste, green wastes and energy crops. This type of biogas comprises primarily methane and carbon dioxide. A general composition of this biogas would be 50 to 70 percent methane, 30 to 40 percent carbon dioxide $(\mathrm{CO} 2)$ and low amount of other gases [2]. Biogas is about 20 percent lighter than air and has an ignition temperature in the range of 650 to $750{ }^{\circ} \mathbf{C}[3]$.

The other principal type which is wood gas can be produced by gasification of wood or other biomass. This type of biogas is comprised primarily of nitrogen, hydrogen and carbon monoxide and can be combusted or oxidized with oxygen [1].

Air contains $21 \%$ oxygen and thus permits the combustion of biogas. This energy release allows biogas to be used as fuel: biogas can be used as low cost fuel in any country for any heating purpose such as cooking [4]. Stoves capable of burning biogas efficiently must be specially designed: the ratio of the total area of burner to the area of the injector orifice should be between 225:1 and 300:1 [5]. Biogas is a renewable fuel, making its production eligible for renewable energy subsidies in some part of the world. Biogas can be compressed, much like natural gas and used to power motor vehicles. It can also be used in modern waste management facilities where it can be used to run any type of heat engine to generate either mechanical or electrical power [6].

Biogas is a clever way of exploiting nature without destroying it, simultaneously solving both energy and manure management problems. The biogas unit is a system in which the three components- biogas plant, animal production and fodder grass plantation form a sustainable natural cycle: The fodder grass feeds the animals, the animals produce their waste as feedstock for the biogas plant, and the biogas plant in turn, provides digested slurry as fertilizer for the plants. Other advantages associated with this method of producing biogas are income generation from the animal milk and meat, the energy and comfort it provides as a clean cooking and lighting fuel, and its ability to reduce deforestation $[6,7]$. It can also be used for lighting, and running farm machinery, irrigation pumps and so on.

The objective of this study was to develop a biogas burner and evaluate the biogas stove for cooking using biogas produced from cattle wastes in a $3 \mathrm{~m}^{3}$ floating drum Indian type biogas plant. 


\section{International Journal of Engineering Applied Sciences and Technology, 2020 \\ Vol. 4, Issue 12, ISSN No. 2455-2143, Pages 11-16 \\ Published Online April 2020 in IJEAST (http://www.ijeast.com)}

\section{MATERIALS AND METHOD}

\section{A. Materials}

1. Materials for Stove Construction: A summary of materials used are: $12 \mathrm{~mm}$ square rod $180 \mathrm{~mm}$ long for the support frame; Legs 105 by $10 \mathrm{~mm}$ diameter round rod for the legs; 150 by $66 \mathrm{~mm}$ diameter round pipe for the mixing tube; Brass thimble for the jet; and $5 \mathrm{~mm}$ thick cast iron for the Burner head.

\section{Description of Biogas Plant}

The biogas plant as shown in Figure 3 is a $3 \mathrm{~m}^{3}$ continuous flow Indian type digester at the Teaching and Research Farm, University of Agriculture, Makurdi, Nigeria. Cattle waste obtained from the Livestock Farm at the location was mixed with water to form a slurry with total solid concentration of 5 $\%$. Feedstock slurry prepared at 2: 1 water to cattle dung mix ratio was fed into the digester at a $100 \mathrm{~kg} / \mathrm{day}$ loading rate for a 30 day retention time. The slurry was anaerobically digested. The feedstock was continuously loaded to provide constant supply of biogas (Methane).

\section{B. Method}

\section{Design Considerations}

i. Unless altered to accommodate adjustments the relative distances between the stove components including the inclination of the legs and burner cap to pot distance are to remain fixed, ensuring that flame colour and the intensity of heat are consistent.

ii. Materials chosen for the construction of the burner cap were chosen to resist high temperatures and prevent melting and speedy corrosion.

iii. The dimension and configuration of the supporting frame and pot stand has been chosen to accommodate various sizes of cooking pots.

iv. The diameter, distribution and number of ports on the burner cap has also been chosen to allow for the production of a stable flame.

v. The Air control valves have been designed to permanently maintain its setting during a cooking operation unless altered.

vi. The diameter of the mixing tube has also been chosen to ensure complete mixing of air and gas before combustion. Cheap and suitable materials have been so selected for construction of this biogas stove as to make the final product affordable.

vii. The entire design has been built to minimal size, weight to ease cleaning and portability.

2. Biogas burner design: The burner was designed on the basis of design assumptions and equations by Sasse et al., in [8]. Table 1 shows the various gas properties and equations that were used in the design.
Table 1: Geometric data for biogas burner design

\begin{tabular}{|c|c|c|c|}
\hline Component/Property & Symbol & $\begin{array}{c}\text { Design } \\
\text { Equation/Basis }\end{array}$ & Dimension \\
\hline Estimated gas flow rate & $Q$ & $Q=c \cdot \Delta p \cdot d_{1}^{2} / S L$ & 5.69 \\
\hline Jet diameter & $\mathrm{d}_{\mathrm{o}}$ & $d_{s}=21(Q / h)$ & 1.1 \\
\hline Diameter of mixing pipe & d & $d=6 d_{0}$ & 6.6 \\
\hline $\begin{array}{l}\text { Maximum length of air } \\
\text { intake hole }\end{array}$ & $\mathrm{L}_{\max }$ & $L_{\max }=7 d$ & 46.2 \\
\hline $\begin{array}{l}\text { Minimum length of air } \\
\text { intake hole }\end{array}$ & $\mathrm{L}_{\min }$ & $L_{\min }=1.35 d$ & 8.91 \\
\hline $\begin{array}{l}\text { Diameter of mixing } \\
\text { chamber }\end{array}$ & $\mathrm{D}$ & $D=1.3 d$ & 8.6 \\
\hline $\begin{array}{l}\text { Length of mixing } \\
\text { chamber }\end{array}$ & $\mathrm{L}$ & $L=1.5 d$ & 9.9 \\
\hline Number of holes & $\mathrm{n}$ & $n=20 d_{n}^{2}$ & 24 \\
\hline $\begin{array}{l}\text { Diameter of flame port } \\
\text { hole }\end{array}$ & $\mathrm{d}_{\mathrm{H}}$ & $\begin{array}{l}\text { Applies for floating } \\
\text { drum biogas plants }\end{array}$ & 0.25 \\
\hline
\end{tabular}

Definition of terms: $S=$ Air density $=1.2 \mathrm{~kg} / \mathrm{m}^{3} ; L=$ distance between manometers. $=0.6 \mathrm{~m} ; h=$ prescribed gas pressure $=0.9 \mathrm{~cm}(W . C)$. Note: All dimensions have been supplied in units appropriate for design equations that require them; All dimensions in the table are in $\mathrm{cm}$ except the estimated gas flow rate $Q$ in $\mathrm{m}^{3} / \mathrm{h}$.

\section{Description of Burner (stove)}

Figure 1 is the design diagram of the stove, and the main components are: the legs (1), injector (6), mixing tube (5), the burner cap (2), support frame (3), gas intake pipe (4), and air control valves (7). The injector is held in position by screwing it into a hole driven on the valve. The injector tapers into a nozzle which enters into the air-gas mixing chamber. The airgas mixing chamber opens into the burner cup or head, where the gas can be ignited. The injector and the air control valve work as a dual purpose unit admitting biogas from the gas intake pipe into the mixing chamber at speeds that create pressure drops in a venturi vacuum effect. This causes regulated air suction at the air-control valve as the injector moves in/out of the mixing chamber. The admitted air (primary air) is entrained into the gas stream to form an air-gas mixture in the mixing chamber. The admitted air must be completely mixed with the biogas. This happens because the pipe is widened to a maximum diameter, which is in constant relation to the diameter of the jet. By widening the gap further, the gas flow-rate is again reduced as the diffuse gas flows to the burner head. The gas then needs more oxygen for final combustion which is supplied by the surrounding air. Figures 1 and 2 represent views from the top and front, of the constructed biogas stove. 
International Journal of Engineering Applied Sciences and Technology, 2020

Vol. 4, Issue 12, ISSN No. 2455-2143, Pages 11-16

Published Online April 2020 in IJEAST (http://www.ijeast.com)

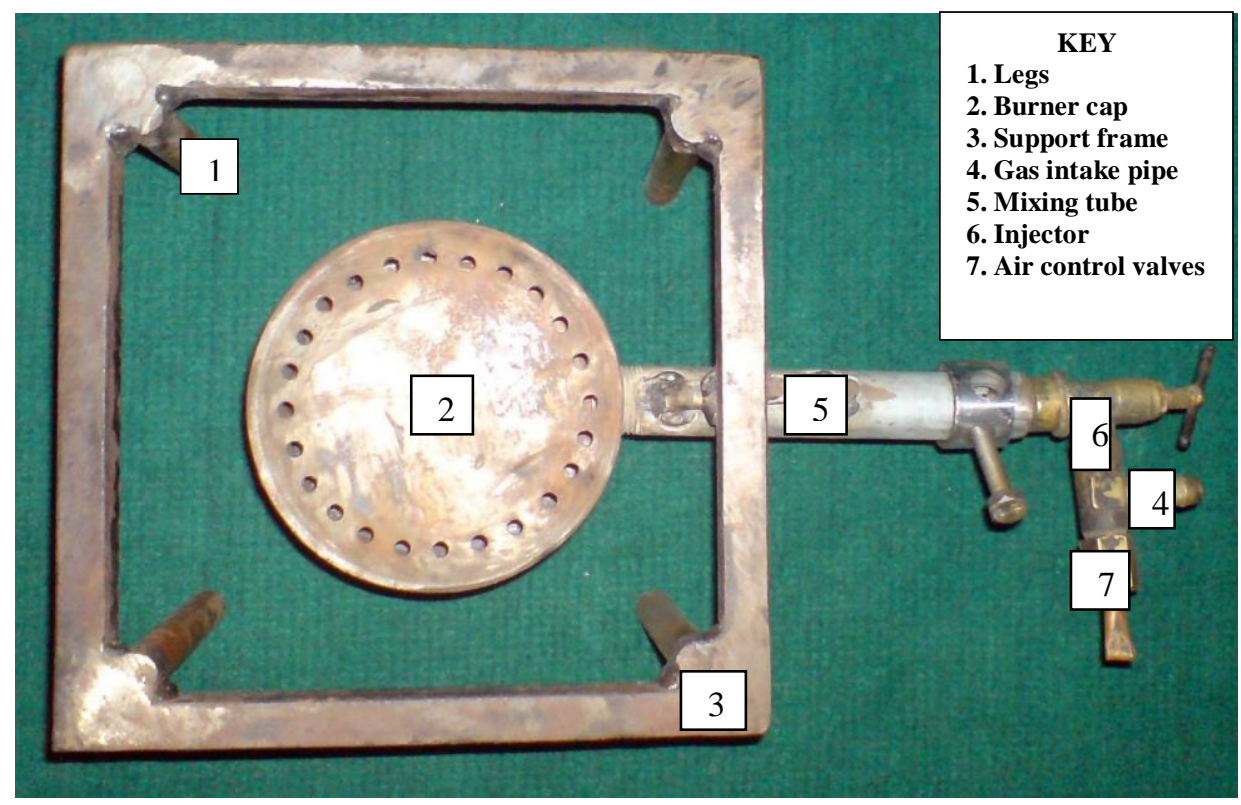

Figure 1: Plan view of the Constructed Stove

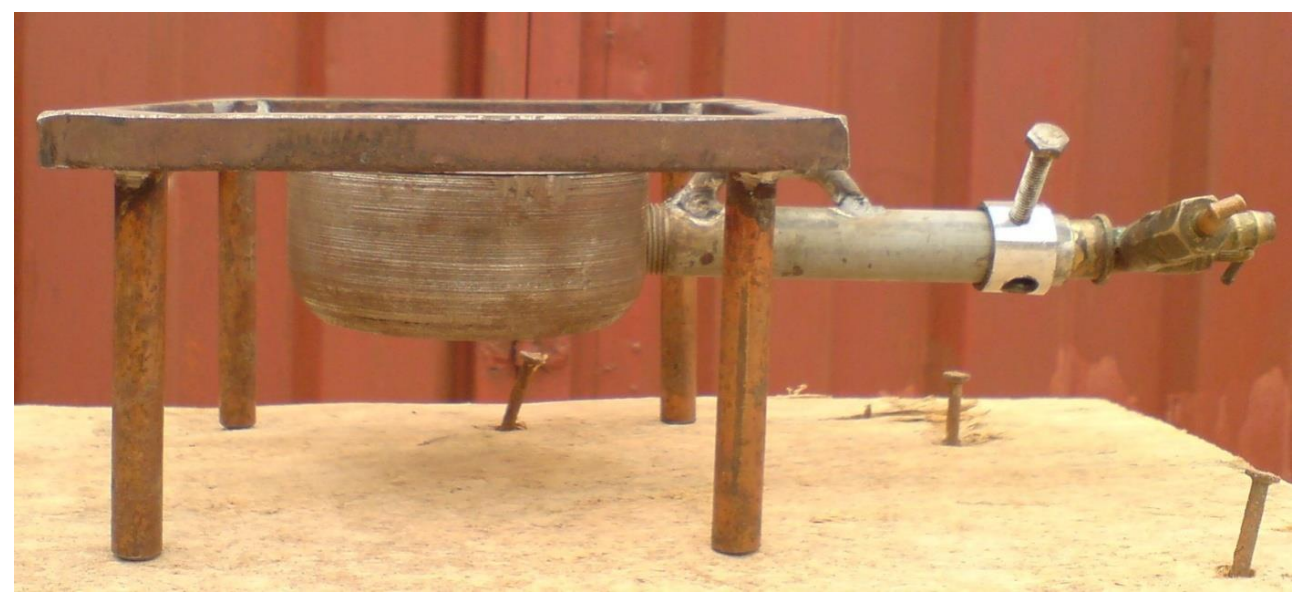

Figure 2: Front view of the Constructed Stove

\section{The biogas plant}

A biogas stove was designed and constructed with burner head, frame, and injector, mixing tube, burner pots and primary air control valve as the main components. The stove was connected to a biogas plant $\left(3 \mathrm{~m}^{3}\right.$ continuous-flow Indian type biogas plant) located at the animal farm in the University of Agriculture, Makurdi. The stove was evaluated by recording the boiling and cooking time for various food stuffs; water, rice, yam and beans.

The gas flows to the stove from the digester; the gas flow rate depends on the pressure in the gas plant and its pipe diameter. With the help of the jet at the inlet of the burner, the speed is increased producing a draft, which sucks air into the pipe. If combustion is perfect, the flame is dark blue and almost invisible in daylight.

\section{Determination of Total Solids}

Total Solids for the slurry in the Biogas plant was determined before use as substrate for the plant. The determination of Total solids is important because there are certain ranges of Total solids within which high biogas yield from cattle dung is permissible. [9] suggested TS range of 7-9 \% and the current study only conducted preliminary tests on slurry samples to ensure that they were within or close to this range for slurry preparation in the biogas plant. Total solids for a particular weight type was determined by oven dry method at $100 \pm 20$ ${ }^{\circ} \mathrm{C}$ for 24 hours and computed from Equation (3). 


\section{International Journal of Engineering Applied Sciences and Technology, 2020 \\ Vol. 4, Issue 12, ISSN No. 2455-2143, Pages 11-16 \\ Published Online April 2020 in IJEAST (http://www.ijeast.com)}

\section{Pressure Drop in Pipes $(\Delta \mathrm{P})$}

Pressure drop was determined from two manometers placed between the digester and the stove. The gas flows from the biogas plant into manometer, A which then conducts the gas through a valve regulated pipe. The other end of this pipe is connected to manometer, B and a stove as shown in Figure 3. When the valve is turned-on, there will be a rise in the left and right manometers to a certain height as $P_{1}$ and $P_{2}$ the difference between $\mathrm{P}_{1}$ and $\mathrm{P}_{2}$ denoted as $\Delta \mathrm{P}$ represents the pressure drop in the pipes.

\section{Performance Evaluation}

Performance evaluation of the stove was carried out by boiling a liter of water, cooking $70 \mathrm{~g}$ a piece of rice, yam and beans and the time taken to complete each task was determined using a stop watch. Time for boiled water was gauged by determining the precise moment for rapid formation of bubbles. Cooking time for the cooked yam, rice and beans were obtained by measuring the cooking time taken for food to become tender. This tenderness was determined by crushing samples of each food item between the fingers. The time taken for all the burner holes to ignite was noted and recorded with the aid of a stop watch. Every evaluation process either involving boiling of water or cooking of food (yam, rice or beans) was replicated three times and a mean value recorded. Mean result values from these replications for the procedures above are presented in Table 2.

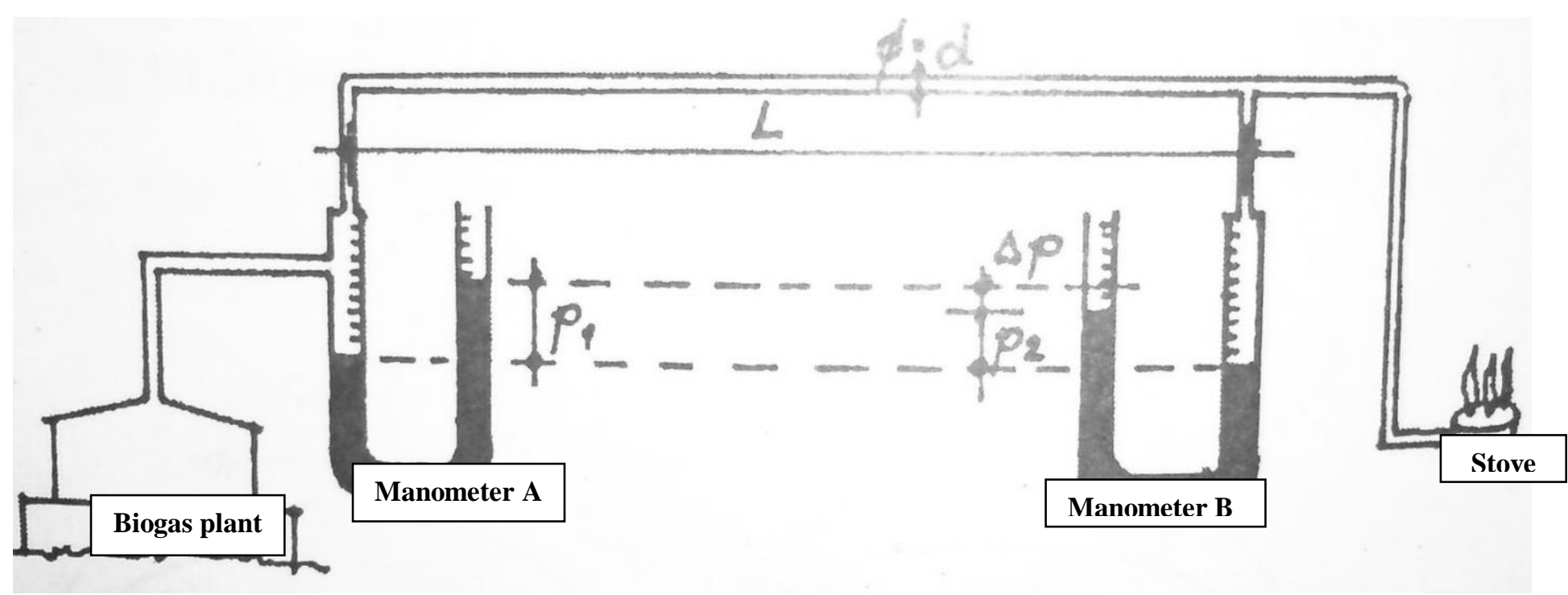

Figure 3: Experimental set up.

\section{Performance Calculations}

a) Cooking Rate (Cr) was determined as in [10] using Equation 1

$C_{r}=\frac{\text { Qwantityof Commodity [ingorl] }}{\text { timetaken }[\text { min] }]}$

b) Thermal Efficiency ( $\boldsymbol{\eta}$ ) was determined as in [10] using Equation 2

$\mathbf{\eta}=\frac{100 \mathrm{Cr}[\mathrm{g} / \mathrm{min}]}{Q\left[\mathrm{~m}^{3} / \mathrm{min}\right]}$ where: $\mathrm{Cr}=$ cooking rate $(\mathrm{g} / \mathrm{min})$,

$\mathrm{Q}=$ gas consumption rate $\left(\mathrm{m}^{3} / \mathrm{min}\right)$

c) Total Solids (TS)

$\operatorname{TS}(\%)=100-\mathrm{MS}$

Where MS $=\frac{100 \text { (Initial weight of sample }- \text { final weight) }}{\text { Initial weight }}$.

\section{RESULTS AND DISCUSSION}

\section{A. RESULTS}

Table 2 and Figure 4 are summaries of results for the biogas stove performance. 
International Journal of Engineering Applied Sciences and Technology, 2020

Vol. 4, Issue 12, ISSN No. 2455-2143, Pages 11-16

Published Online April 2020 in IJEAST (http://www.ijeast.com)

Table 2: Summary of Mean Values for Using Biogas Stove in Boiling Water, Cooking Rice, Yam and Beans

\begin{tabular}{|c|c|c|c|c|c|c|}
\hline Items & $\begin{array}{l}\text { Mean } \\
\text { Quantities } \\
(\mathbf{l} ; \mathrm{g}) \\
\end{array}$ & $\begin{array}{l}\text { Time taken } \\
(\min )\end{array}$ & $\begin{array}{l}\text { Cooking Rate } \\
\text { ( 1/min ; g/min) }\end{array}$ & $\begin{array}{l}\text { Biogas Consumption } \\
\left(\mathbf{m}^{3}\right)\end{array}$ & $\begin{array}{l}\text { Ignition time } \\
\text { for burner } \\
\text { Holes (s) }\end{array}$ & Efficiency $(\%)$ \\
\hline Water & $\begin{array}{c}1 \\
(0.00)\end{array}$ & $\begin{array}{l}5.00 \\
(0.00)\end{array}$ & $\begin{array}{c}0.20 \\
(0.00)\end{array}$ & $\begin{array}{c}0.474 \\
(0.000)\end{array}$ & $\begin{array}{l}1.00 \\
(0.00)\end{array}$ & $\begin{array}{l}42.00 \\
(0.00)\end{array}$ \\
\hline Rice & $\begin{array}{l}70.17 \\
(0.00)\end{array}$ & $\begin{array}{l}34.33 \\
(0.101)\end{array}$ & $\begin{array}{c}2.044 \\
(0.006)\end{array}$ & $\begin{array}{l}3.254 \\
(0.055)\end{array}$ & $\begin{array}{c}1.00 \\
(0.00)\end{array}$ & $\begin{array}{c}63.00 \\
(0.868)\end{array}$ \\
\hline Yam & $\begin{array}{l}70.01 \\
(0.00)\end{array}$ & $\begin{array}{l}34.66 \\
(0.172)\end{array}$ & $\begin{array}{l}2.020 \\
(0.010)\end{array}$ & $\begin{array}{l}3.286 \\
(0.085)\end{array}$ & $\begin{array}{l}1.00 \\
(0.00)\end{array}$ & $\begin{array}{c}61.00 \\
(1.287)\end{array}$ \\
\hline Beans & $\begin{array}{l}70.00 \\
(0.00)\end{array}$ & $\begin{array}{c}49.33 \\
(0.297)\end{array}$ & $\begin{array}{c}1.419 \\
(0.009)\end{array}$ & $\begin{array}{c}4.778 \\
(0.023)\end{array}$ & $\begin{array}{c}1.00 \\
(0.00)\end{array}$ & $\begin{array}{c}30.00 \\
(0.041)\end{array}$ \\
\hline
\end{tabular}

Note: Values enclosed in parenthesis are standard deviations.

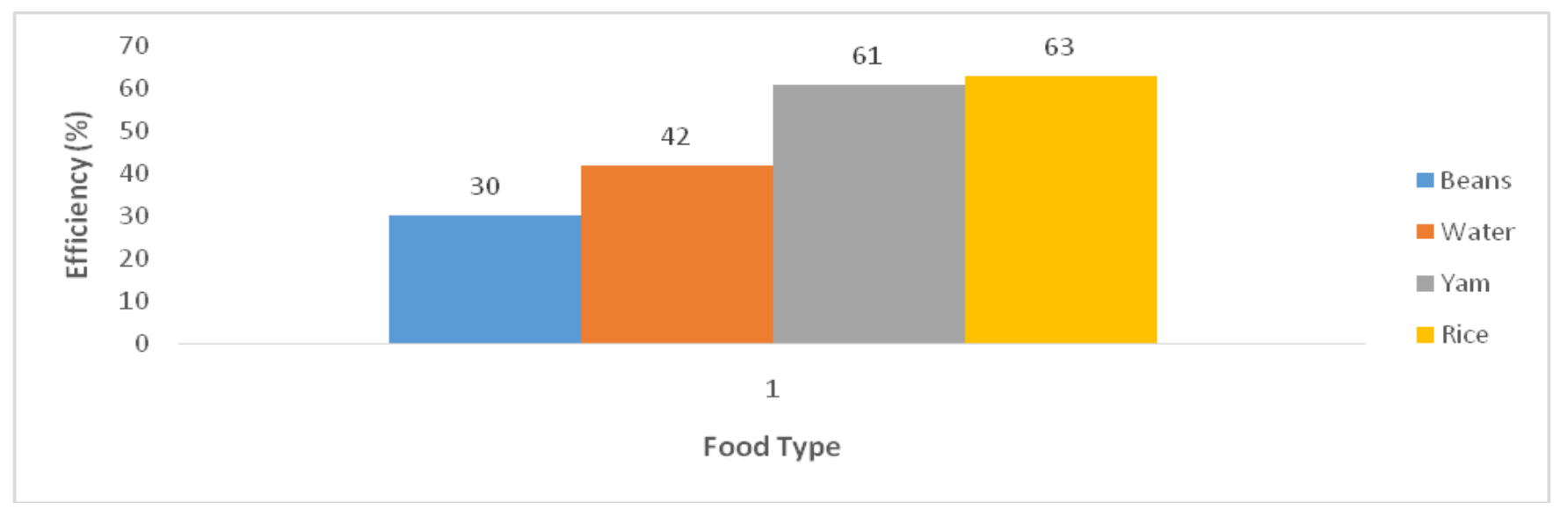

Figure 4: Gas burner Efficiencies with varying Food-type

\section{B. DISCUSSION}

The boiling rate as in Table 2 was $0.21 / \mathrm{min}$ while the cooking rates were $2.044 \mathrm{~g} / \mathrm{min}, 2.020 \mathrm{~g} / \mathrm{min}, 1.419 \mathrm{~g} / \mathrm{min}$ for rice, yam and beans respectively. The mean biogas consumption were $0.474 \mathrm{~m}^{3}, 3.254 \mathrm{~m}^{3}, 3.285 \mathrm{~m}^{3}$ and $4.778 \mathrm{~m}^{3}$, for boiling water, cooking rice, cooking yam and cooking beans respectively. These biogas consumption values were favourably lower than values from other authors for water and beans $[8]$.

The flame was stable throughout the period of the cooking. The time taken for all jets to ignite was about a second for all the cooking. Time for boiled water was noted at the start of rapid formation and rising of bubbles. Time for cooking rice, yam and beans was determined by tasting the cooked products. Cooking and boiling time is important to energy conservation efforts as it indicates the quantity of biogas expended per cooking time.
Figure 4 is a comparison of cooking efficiencies for the various commodities. It can be observed that the stove performed best during the cooking of rice at $63 \%$ followed by yam at $61 \%$, then beans at $30 \%$. The efficiency for boiling water was $42 \%$. These values compare favorably with values obtained by [11] for a burner with scrubbing unit, with overall efficiency of $60 \%$. A fairly similar biogas stove efficiency of $53 \%$ has also been reported [8]. Efficiency values by these authors were lower than those in the current study. An explanation for this is the lower gas consumption rate and smaller jet diameter of the burner in the current study, than the Itodo stove for similar quantities of cooked items.

The low stove cooking efficiency of $30 \%$ for beans may have resulted from the effects of varying wind speed and direction as the cooking experiment was conducted outdoors [12]. Secondly, the biogas plant used for this study may have issued biogas of poor quality during the beans cooking period since it had no separate compartment for gas purification [13]. This 


\section{International Journal of Engineering Applied Sciences and Technology, 2020 \\ Vol. 4, Issue 12, ISSN No. 2455-2143, Pages 11-16 \\ Published Online April 2020 in IJEAST (http://www.ijeast.com)}

caused poor combustion as the proportion of methane and hydrogen in the cooking gas was lower than required.

It can also be observed that the time it took to do the cooking of beans was marginally higher at the start of the cooking than it was for all replicates. This was because cooking time depends on cooking efficiency which in turn, depends on the specific heat capacity of the cooking pot $[\mathbf{1 4}, \mathbf{1 5}]$. Hence, a heat energy amount equal to the heat capacity of the cooking pot and the heat capacity of the cooked item had to be supplied during the initial experiment. However, succeeding replications for an item to be cooked required an energy amount that approximately equaled only its heat capacity since the cooking pot had already been heated. Secondly, a higher cooking time for beans can only be expected considering that it has a higher specific heat capacity than the other two solid foods $[16,17]$.

\section{CONCLUSION}

i. The stove performed satisfactorily with a boiling rate of $0.2 \mathrm{lit} / \mathrm{min}$, cooking rates of $2.044 \mathrm{~g} / \mathrm{min}, 2.020$ $\mathrm{g} / \mathrm{min}$, and $1.419 \mathrm{~g} / \mathrm{min}$ for rice, yam and beans respectively.

ii. The mean biogas consumption were $0.474 \mathrm{~m}^{3} / \mathrm{min}$, $3.254 \mathrm{~m}^{3} / \mathrm{min}, 3.285 \mathrm{~m}^{3} / \mathrm{min}$ and $4.778 \mathrm{~m}^{3} / \mathrm{min}$ for boiling water, cooking rice, cooking yam and cooking beans respectively. These biogas consumption rates were favourably lower than those of other authors for water and beans.

Efficiency values higher than those of previous works were achieved. They are $42 \%$ for boiling water, $63 \%$ for cooking rice, $61 \%$ for cooking yam and $30 \%$ for cooking beans were a realized.

\section{REFERENCES}

[1] Speight, JG. (2011) The Biofuels Handbook.Thomas Graham House, Science Park, Milton Ro. Cambridge, CB4 0WF UK. Royal Society of Chemistry.

[2] Yimer, S., and Sahu, OP. (2014). Biogas as Resources of Energy. International Letters of Natural Sciences, Vol.4, pp. 1-14.

[3] Raja, IA., and Wazir, S. (2017). Biogas Production: The Fundamental Processes. Universal Journal of Engineering Science Vol. 5, No.2, pp. 29-37, 2017.http://www.hrpub.org P. S. Huang, C. S. Chiang, C.

[4] Akinbami, JF., Ilori, MO., Oyebisi, TO., Akinwumi, IO., and Adeoti, O. (2001). Biogas Energy Use In Nigeria: Current Status, Future Prospects and Policy
Implications. Renewable and Sustainable Energy Reviews,Vol. 5, No 1, pp. 97-112, 2001.

[5] Marchaim, U.Biogas (1992) Processes for Sustainable Development, Food and Agriculture Organisation Agricultural services Bulletin, 95, 89-90. 1992.

[6] Seadi, A.T., Rutz, D., Prassl, H., Köttner,M., Finsterwalder, T., Volk, S. and Janssen, R. (2010). Biogas Handbook. Denmark.University of Southern Denmark.

[7] Subedi, M., Matthews, RB., Pogson, M., Abegaz, A., Balana, BB., Oyesiku-Blakemore, J., and Smith, J. (2014). Can Biogas Digesters Help to Reduce Deforestation in Africa? Biomass and Bioenergy, Vol. 70, pp. 87-98.A.T..

[8] Itodo, IN., Agyo, GE., and Yusuf, P. (2007). Performance Evaluation of a Biogas Stove for Cooking in Nigeria. Journal of Energy in Southern Africa, 18(4), 1418.

[9] Widiasa, IN. and Seno, J. (2010). The Influence of Total Solid Contents on Biogas Yield from Cattle Manure Using Fluid Rumen Inoculum. Energy Research Journal, Vol.1, No. 1, pp. 6-11.

[10] Obada, DO., Obi, AI., Dauda, M., and Anafi, FO. (2014). Design and Construction of a Biogas Burner. Palestine Technical University Research Journal, Vol..2, No. 2, pp. 35-42..

[11] Kurchania, AK., Panwar, NL., and Pagar, SD. (2011). Improved Biogas Stove with Scrubbing Unit for Household Use. Waste and Biomass Valorization, Vol.2, No. 4, pp. 397.

[12] Viegas, DX. (2004). Slope and Wind Effects on Fire Propagation. International Journal of Wildland Fire, Vol.13, No. 2, pp.143-156.

[13] González-Fernández, C., and García-Encina, PA. (2009). Impact of Substrate to Inoculum Ratio in Anaerobic Digestion of Swine Slurry. Biomass and Bioenergy, Vol.33, No.8, pp.1065-1069.

[14] Harmim, A., and Boukar, M. (2008.). Experimental Study of a Double Exposure Solar Cooker with Finned Cooking Vessel.. Solar Energy, Vol. 82, No. 4, pp. 287-289.

[15] Lahkar, PJ., and Samdarshi, SK. (2010). A Review of the Thermal Performance Parameters of Box Type Solar Cookers and Identification of Their Correlations. Renewable and Sustainable Energy Reviews, Vol.14, No. 6, pp. 1615-1621. 2010.

[16] American Society of Heating, Refrigerating and AirConditioning Engineers -ASHRAE(2006). Atlanta, GA. 2006.

[17] Mohapatra, D. and Bal, S., (2003). Determination of Specific Heat and Gelatinization Temperature of Rice using Differential Scanning Calorimetry In 2003 ASAE Annual Meeting (p. 1). American Society of Agricultural and Biological Engineers. 